\title{
高圧撮影に於ける銅濾過板の効果について
}

\author{
結核予防会京都府支部西ノ京健康相談所 森谷誠一・三 宅 鉄 雄
}

（論交受付 昭和32年10月15日）

\section{ON THE EFFECT OF COPPER FILTER FOR THE HIGH VOLTAGE RADIOGRAPHY}

\section{By SEITI MORITANI}

TETSUO MIYAKE

Kyoto Anti-Vuberculosis Association.

(Articul received : Octover 15, 1957)

\section{Summary}

The following results are obtained by the investigation of filters for the high voltage radiography:

1) Filter of $1.58 \mathrm{~mm} \mathrm{Al}$ is equivalent to it of $0.05 \mathrm{~mm} \mathrm{Cu}+0.1 \mathrm{~mm} \mathrm{Al}$, as to the absorption of $\mathrm{X}$-ray emitted from the X-ray tube at $130 \mathrm{kV}$. The H.V.L. of the transversed X-ray through the former filter is $4.4 \mathrm{~mm} \mathrm{Al}$ while the H.V.L. of the X-ray though the latter is $5.8 \mathrm{~mm} \mathrm{Al}$.

2) Filter of $1.18 \mathrm{~mm} \mathrm{Al}$ is equivalent to it of $0.05 \mathrm{~mm} \mathrm{Cu}+0.1 \mathrm{~mm} \mathrm{Al}$, as to the transversed $\mathrm{X}$-ray intensity though $8 \mathrm{~cm}$ paraffin and crossed Lysholm grid in the range of tube voltage of $80 \sim 140 \mathrm{kV}$. The intensity of the incident X-ray to the paraffin using the former filter is more than that using the latter filter.

3) The contrast between $\mathrm{Al}$ steps (representing bone tissue) and the paraffin block on X-ray film can be diminished more by using $0.05 \mathrm{~mm} \mathrm{Cu}+0.1 \mathrm{~mm} \mathrm{Al}$ filter than the case using $1.18 \mathrm{~mm} \mathrm{Al} \mathrm{filter,} \mathrm{leaving} \mathrm{the}$ contrast between plastic plates (representing soft tissue) and the paraffin block almost the same.

本論文の要旨は昭和32年 6 月23日神戸に於ける第52回 日本医学放射線学会関西部会に於て公表した。

\section{内 容 梗 概}

高压撮影用滤過板として $0.05 \mathrm{Cu}+0.1 \mathrm{Al}$ を使朋し, こ れとアルミ濾過板とを比較して次の結果を得た。

1） $130 \mathrm{kV}$ に於いて同一の減弱を生ずるアルミ濾過板 は $1.58 \mathrm{~mm}$ であったが，乙れらを透過したX線の半価層 は $0.05 \mathrm{Cu}+0.1 \mathrm{Al}$ では Al 5.8mm であり, $1.58 \mathrm{Al}$ では $\mathrm{Al} 4.4 \mathrm{~mm}$ であった。

2） $8 \mathrm{~cm}$ パラフインとクロスグリツドを透過するX線 量が $80 \sim 140 \mathrm{kV}$ の範囲で, $0.05 \mathrm{Cu}+0.1 \mathrm{Al}$ 濾過板の場 合に等しいアルミ濾過板の曆さは $1.18 \mathrm{~mm}$ であったが, 表面射入量は $1.18 \mathrm{Al}$ のきの方が大であった。

3） $0.05 \mathrm{Cu}+0.1 \mathrm{Al} 1.18 \mathrm{Al}$ にくらべて, アクリラ イト段階 (博組織) のコントラストに殆ど影響を与えな いで Al 段階（骨）とパラフインとの間のコントラスト をさらに低下させるととが出来る.

\section{I. 緒言}

最近䯧压熶影法が推奨され，其の基礎的及び臨味的方 面の研究の中に，㴔過板に関する報告导可成り見られる に致った．其の内滤過板の厚さに関しては, Trout, Kelley, Cathey, Clark は全フイルターとして $3 \mathrm{~mm} ア ル ミ$ ニーウム（以下 Al 又はアルミと略称す）程度を推奖し

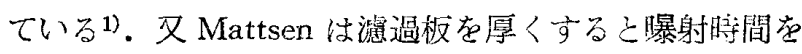
延長せ祖ばなら欢不利があるから，其の限度は凡を $2 \mathrm{~mm}$ Al 位までであるとのべているが1)，とこでは現在一般に 用いられている $1 \mathrm{mmAl}$ 程度に近いX線減弱度を有する $0.05 \mathrm{~mm}$ 銅（以下 $\mathrm{Cu}$ と略称す） $+0.1 \mathrm{mmAl}$ フイルター を使用した。

銅とアルミの同一減弱度に関して, Cu $1 \mathrm{~mm}$ は Al 17.5 $\mathrm{mm}$ に相当すると云われている2). 従って $0.05 \mathrm{~mm} \mathrm{Cu}+$ $0.1 \mathrm{mmAl}$ と $1 \mathrm{mmAl}$ は近似的である. 筆者泭加アル ミ濾過板として 0.1mmAl を用いたが, Mutscheller ${ }^{3)}$ は 銅濾過板に附加すべきアルミの厚さは 0.25 万至 $0.5 \mathrm{~mm}$ で 
充分である上称して居り，又 Grunberg4) は附加アルミ 濾過板は不要であるこ称している。但してれ等はレント ゲン治療の場合であり，彰断用として銅滤過板を使用す る己き溒，距離より短時間照射するのであるから，附 加アルミ滤過板は例入必要であるこしても $0.1 \mathrm{~mm}$ あれ ば立分ですと思う。

銅又はアルミ演過板を通過したX線の强さを同一とし ても，銅にて濾過されたX線は短波長線の割合が多く， アルミでは長波長線の多い事は周知の通りであるが，此 の特徽から銅濾過板を嗑圧撮影に利用すれば，アルミ濾 過板のうきより線質う硬くなり，透過線量は増加し，骨 陰影を更に消退せしめ得るここが考えられる。筆者はこ の点に着目し銅濾過板とアルミ濾過板との比較奏験を行 つたので，其の結果をここに報告し諸賢の御批判を仰ぐ 次第である。

\section{II. 実験}

此の央駼に使用した装置及ざ秋料汹次の通りである。 (1)島津製，貴船号 $150 \mathrm{kV}, 0.2 \mu \mathrm{F}$ ，波尾切断型高压印加 コンデンサ式装置

管球 $\mathrm{SDO}-3 \mathrm{H}$

(2)線量計 島津製標準型「レントゲン」線量測足器

(3)濃度計 島津製山部式濃度計

(4)グリッド ルシデックス $(5: 1)$

增感紙 楂光 FS

フイルム 富士商感度

以後1に関しては装置の名称及定格容最等の記载を省 略し，2(3)文び(4)は以下单に線量計，灌度計攵はグリッ ドし称する。

\section{実験 1 線質に関する検討}

奏験序法


と同一減弱度を有するアル之滤過板の厚さ它, 線星計に 依って $100 \mathrm{kV}$ 加 $140 \mathrm{kV}$ 汽测定した処， $1.58 \mathrm{~mm}$ で一 致した。これ等の滤過板を夫々使用した場合について， 次の条件の下に半酒周測定用アルミ溧過板の厚さを次第 に增し作ら測定し, 減弱四線を求めた。

测定条件， $130 \mathrm{kV} ， 0.5 \mathrm{~mA}$ 連綂，焦点線量計間距離 $110 \mathrm{~cm}$

実験成縝及び苧察

以上の実験の結果第 1 図に示吉娍弱姡線を得た。

$1.58 \mathrm{Al}$ 鰓過板を通過したX線の半価圈は $\mathrm{Al} 4.4 \mathrm{~mm}$ で あるのに対し， $0.05 \mathrm{Cu}+0.1 \mathrm{Al}$ 濾過板の場合の半価首は Al $5.8 \mathrm{~mm}$ であった。半価圈が大なる程有効波長は短く

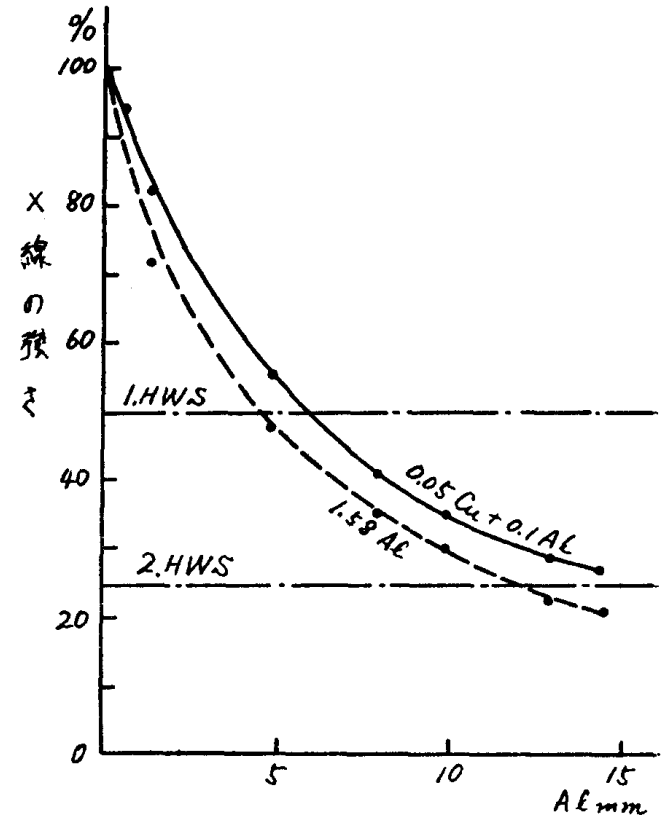

第 1 図
$0.05 \mathrm{Cu}+0.1 \mathrm{Al}$

Filter 亿依る線量減率率 電压 $130 \mathrm{kV}$

なる。即ち銅で濾過されたX線の方が硬いことを示して いる。

\section{実験 2 曝射量之透過線量に関する検討}

線質が異れば同一の被写体に対して射入方分線量と， これを透過する線量この比る亦異る事は当然考へられ る. $0.05 \mathrm{Cu}+0.1 \mathrm{Al}$ 濾過板で滤過されたX線の場合と， 同一の被写体透過線量を得るに要する゙ルミ滤過板の厚 さを求內，更にこれ等の濾過板を使朋したときの被写体 表面射入量己，透過線量との比を較べる為次の実験を行 2 ?.

案 騟 方 法

第2图の様に焦点線量計間距離 $125 \mathrm{~cm}$, 焦点から $8 \mathrm{~cm}$ パラフイン汽の距離を $100 \mathrm{~cm}$ として,ファントーム線量 計間にダリツドを 2 枚交叉して括入し， $80 \mathrm{kV}$ から 140 $\mathrm{kV}$ 迄 $2 \mathrm{~mA}$ 連続で測定した処，0.05 Cu+0.1 Al 漶過板

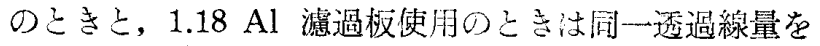
香しな。

次にファントームとグリツドを除き，焦点線量計間距 離を $100 \mathrm{~cm}$ （焦点フアントーム前面間距離）として, 各

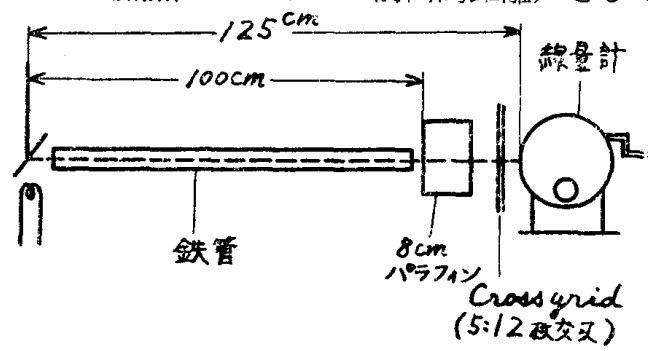

第 2 四 
電圧下図一管電流で表面射入量を測定した。

実験の成績及ざ考察

実験の結果は第 1 表及ご第 3 図に示す様に，透過線量 は常に同一の価を示しながら，管電圧上暑に従って増加

第 1 表 被写体表面射入量と透過線量の比較

\begin{tabular}{|c|c|c|c|c|c|c|}
\hline \multicolumn{3}{|c|}{$0.05 \mathrm{Cu}+0.1 \mathrm{Al}$} & \multirow{2}{*}{$\begin{array}{l}\text { Filter } \\
\begin{array}{c}\text { 電厈 } \\
(\mathrm{kV})\end{array}\end{array}$} & \multicolumn{3}{|c|}{$1.18 \mathrm{Al}$} \\
\hline $\begin{array}{c}\text { 表面射入 } \\
\text { 量 }\left(I_{0}\right)\end{array}$ & $\mid$ & $\begin{array}{l}\frac{I}{I_{0}} \times \\
100 \%\end{array}$ & & $\begin{array}{c}\text { 表面射入 } \\
\text { 量 }\left(I_{0}\right)\end{array}$ & \begin{tabular}{|l} 
透過線 \\
量 $(I)$
\end{tabular} & $\begin{array}{l}\frac{I}{I_{0}} \times \\
100 \%\end{array}$ \\
\hline $\begin{array}{r}500 \mathrm{mr} / \\
\mathrm{min}\end{array}$ & $\begin{array}{r}40 \mathrm{mr} / \\
\mathrm{min}\end{array}$ & 7.3 & 80 & $\begin{array}{r}570 \mathrm{mr} / \\
\mathrm{min}\end{array}$ & $\begin{array}{r}40 \mathrm{mr} / \\
\mathrm{min}\end{array} \mid$ & 6.7 \\
\hline $740 "$ & $60 "$ & 8.5 & 100 & $900 "$ & $60 "$ & 7.0 \\
\hline $1,080 "$ & $100 "$ & 9.0 & 120 & $1,170 "$ & $100 " \prime$ & 8.3 \\
\hline $1,210 "$ & $110 "$ & 9.3 & 130 & $1,290 "$ & $110 "$ & 8.7 \\
\hline $1,240 "$ & $130 "$ & 10.2 & 140 & $1,460 "$ & $130 "$ & 8.7 \\
\hline
\end{tabular}

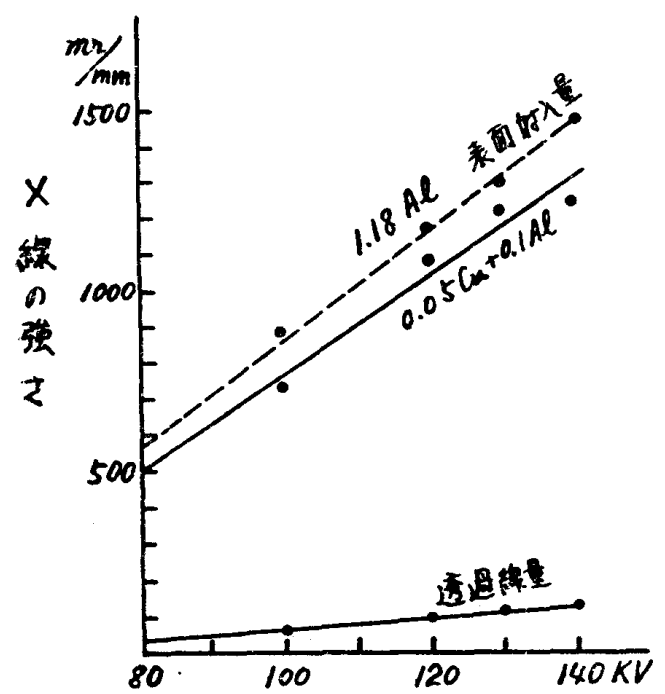

第 3 図问一透過線量特の裁配射入量 西流 $2 \mathrm{~mA}$ パラフィン $80 \mathrm{~mm}$ Cross grid (5:1 2 枚交叉)



第 4 図 $8 \mathrm{~cm}$ パラフィン (Cross grid 5:1 2 枚交叉) に対 多るX線透過㻭
す台方，表面射

入量は $1.18 \mathrm{Al}$ 濾過板を使用し たときの方方部 に大である，即 ち銅濾過板の使 用に依って曝射 線量の減少する 事を示している。 又第 4 闵は此の 実験方方算出し た透過染で，
$0.05 \mathrm{Cu}+0.1 \mathrm{Al}$ 淲過板使用のしきの方が大である。
不均等X線の半価層をdとすれば，てれに相当する減 剭係数 $\mu$ は次式で与えられる5).

$$
\mu d=0.69 \text { 従つて } \mu=0.69 / d
$$

銅濾過板を使用すればアルミ濾過板のときより，これ 等を通過したX線のdが大となるこしは既化述べた処で



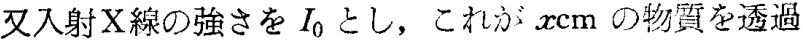
した後の強さを $I$ とすれば炊の減弱の式が与えられら5).

$$
I=I_{0}(f / f+x)^{2} e^{-\mu_{x}}
$$

但し $f$ は焦点より物質表面迄の距離である。

然るに $\mu$ の価は銅滤過板を使用したときの方がです るからIは大きくなりアアルミ濾過板を使用して同一照 射条件で，これと同じ価のI在得るにはアルミの愿さを 減じて $I_{0}$ の価を大きくしなければならないＩの唒方同 一なれば $I_{0}$ の価の小なる方方透過淬は大であり，被写体 の被曝線量の減少するこしは少然である。

被曝量の減少する事は高圧撮影の利点の一つとして挙 げられていることは周知の通りであるが，其の效果は鎷 濾過板の使用に作って更に大こなる事が云える。

\section{実験 3 対照度に関する検討}

胸部泉厓撮影の利点しして，管電压方高くなる程省組 織と軟部組織間のコントラストが低下し，骨丞影力渚し く消退し，これに重った血管や病果陰影の診断う容易に なり，又一枚の写真に現出される被写部位の範柬方広人

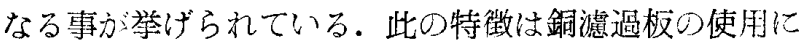
よって更に强く現れることが，今迄のべた実騟結果から 推して考えられるので，次の奏験学行った。

実験布法

骨とアルミこの減弱係数依近似值走示すので6)，兴の 代りにアルミ板を使用した，又軟部組織や水の代用とし て，その散悡败収の模槏ゔ近以的上云われているアクリ ライトを使用した。

実験の条件は次の通りである。

ファントーム $8 \mathrm{~cm}$ パラフイン

アルミニ一ウム段監 摩さ $0.5 \mathrm{~mm}$ 愊 $1 \mathrm{~cm}$ の板を約 1.2 $\mathrm{cm}$ 每に重好て 5 段階已した。

アクリライト段階愿さ $3.4 \mathrm{~mm}$ 幅 $5.8 \mathrm{~cm}$ ののを 約 $1.2 \mathrm{~cm}$ 短に重权て 5 段湝しし た。

管 電 王 $\quad 100 \mathrm{kV}, 120 \mathrm{kV}, 140 \mathrm{kV}, 150 \mathrm{kV}$

F P D $150 \mathrm{~cm}$

現像䔰士レンドールにて $20^{\circ} \mathrm{C} 5$ 分 間，同時現像した。

第 5 図の樣にグリッドを使用し，アルミ及ざアタリラ 
イトの段階をファントームの管球側に装着し, $0.05 \mathrm{Cu}+$ $0.1 \mathrm{Al}$ こ $1.18 \mathrm{Al}$ の濾過板を交互に使用しながら, 各電 圧下で撮影して。

実験成績及び考察

此の実験に

依って得てる

8 枚の写真で,

ファントーム

のみの部分の

濃度注1,7一

1.9 であるか

ら,フイルム

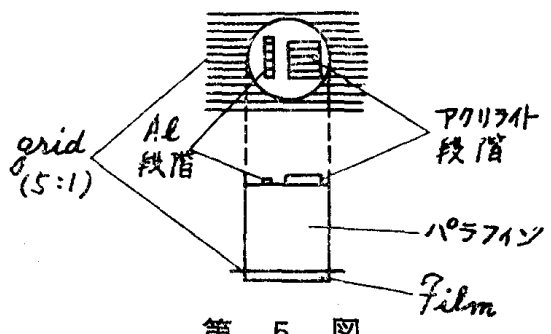

の示性曲線の直線と見做し得る部分の中に包活される。

第 2表 $\mathrm{Al}$ 段階と其の周辺との濃度差



第3表 アクライト段階と其の周辺との濃度差

\begin{tabular}{|c|c|c|c|c|c|c|c|c|}
\hline \multicolumn{5}{|c|}{$0.05 \mathrm{Cu}+0.1 \mathrm{Al}$} & \multicolumn{4}{|c|}{$1.18 \mathrm{Al}$} \\
\hline \multicolumn{4}{|c|}{$\begin{array}{l}3.4 \mathrm{~mm} \text { アク } \\
\text { ライトの段階 }\end{array}$} & \multicolumn{5}{|c|}{ 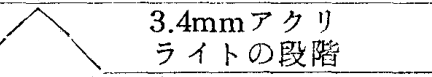 } \\
\hline$\times 1$ & $\times 2 \times 3$ & $\times 4$ & $\times 5$ & $\mathrm{kV}$ & $\times 1$ & $\times 2$ & $\times 3 \times 4$ & $\times 5$ \\
\hline 0.08 & 0.140 .18 & 0.25 & 0.30 & 100 & 0.07 & 0.11 & 0.160 .26 & 0.30 \\
\hline 0.04 & $0.09: 0.13$ & 0.18 & 0.22 & 120 & 0.08 & 0.11 & 0.150 .20 & 0.26 \\
\hline 0.04 & $0.08: 0.13$ & 0.18 & 0.24 & 140 & 0.04 & 0.08 & $0.14 \mid 0.19$ & 0.26 \\
\hline 0.05 & 0.080 .13 & 0.17 & 0.23 & 150 & 0.03 & 0.08 & 0.130 .19 & 0.22 \\
\hline
\end{tabular}

第 2 表之第 3 表はこれぞれ $100 \mathrm{kV} \sim 150 \mathrm{kV}$ の電压下に 於けるアルミ又はアクリライトの各段階と，其の周辺と

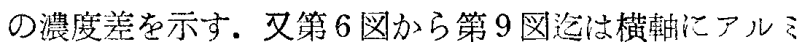
又はアクリライトの段階（枚数）を取り，縦軸に洗濃度 の差を取ったものである。100kV から，150kV 迄の垎図 共(1)はクリライト段階で，(2)はアルミ段階である。 又 実線注銅濾過板で点線はアルミ濾過板を使用したさきで ある。

各図表に示す通り，何れもアルる段階と其の周辺にの コントラストは Al 濾過板のときより銅滤過板を使用し た場合の方が低下が目立っている．然しアクリライト段 階と其の周辺とのコントラストは，何れを使用しても殆
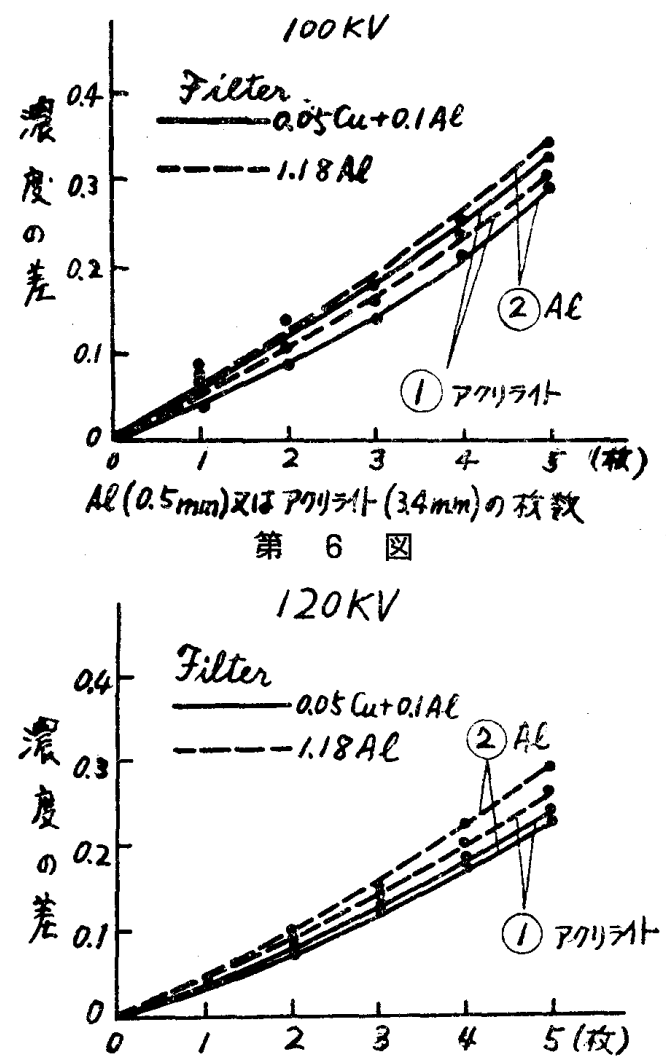

Al $(0.5 \mathrm{~mm})$ 又(17Pm) 5 什 $(3.4 \mathrm{~mm})$ の故教

第 7 图



第 8 図

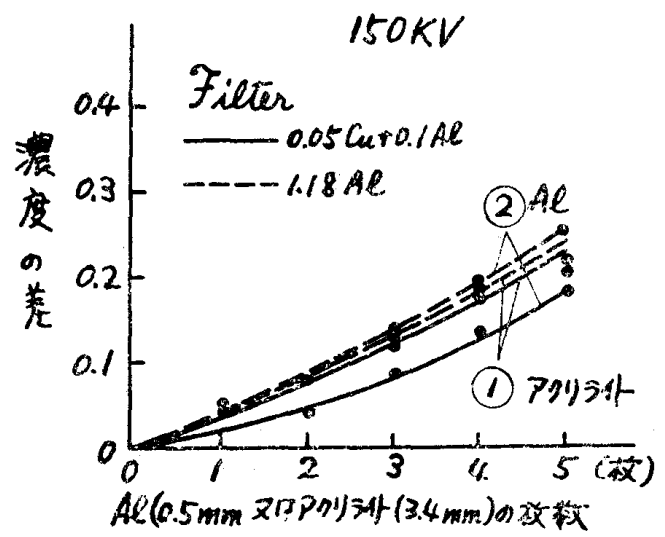

第 9 図 
ぞ同樣である，其の傾向は $140 \mathrm{kV}$ に於て最も著明であ ot.

又第10図一第12図は或一定の段階之其の周辺との濃度 差の, 各電圧下に於ける様子を示したもので, 横軸に電 王を取り，縦軸には濃度の差を取ったものである。

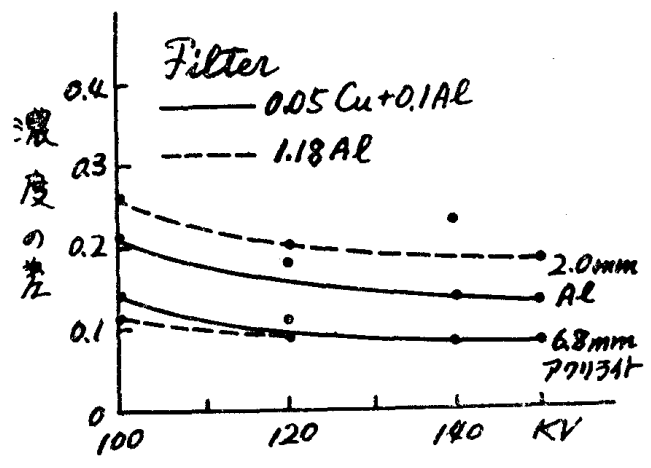

第 10 図



第 11 図

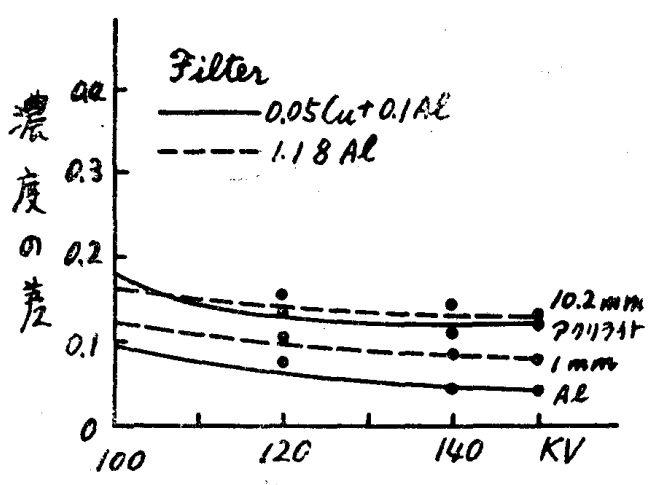

第 12 図

此の実験の結果, 銅滤過板の使用によってアルミ濾渦 板の上きより更に $\mathrm{Al}$ (骨) 陰影は消退するが，アクリラ イト（軟組織）とパラフインの間のコントラストには殆 ど変化を与えない事を示した。

管電圧の低いときのX線の娍弱は主として吸収によ る, 従って骨と軟組織間のコントラストが著しくつくの であるが,管電圧の上曾伴い财収は急激に小さくなり，

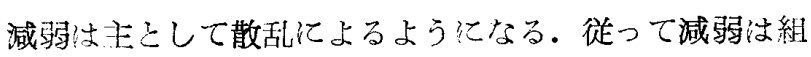

織の密度と厚さの積で効いてく当ようになる。其の理由 として散乱係数は吸収係数の場合任ぞX線の波長や物質 の原子番号に影響されない事方挙げられている，

以上の事柄から”銅滤過板を”使用した場合を考察する とアアルミ濾過板を使用した上きよりも線質方硬くなる 結果しして, 此の央駼維果少得られたことになる。

\section{III. 総括及び考按}

Cu $1 \mathrm{~mm}$ と $\mathrm{Al} 17.5 \mathrm{~mm}$ は同一のX線減弱度を有すと 云われている2).

従って $\mathrm{Al} 1=\mathrm{Cu} 10 / 175$ 更々 $\mathrm{Al} 1 \doteqdot \mathrm{Cu} 0.05+\mathrm{Al} 0.1$ と なる，然し濾過板の純度や厚さの唄差侤って異ると云 われている. Holthusen 汶 $\mathrm{Al}$ に $0.5 \%$ の鉄か混入すると

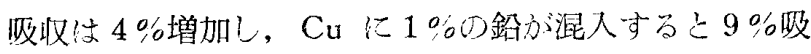
收方增加方当已称している7).又中堀氏7は市販の濾過板 の中には表示の厚さが 1 制近くも違っていることがある 上称している，更に此心等式は管電压に伥って吕変化す る事方洘光られる。


$100 \mathrm{kV}$ から $140 \mathrm{kV}$ 迄減弱度が同一であった。然し之等

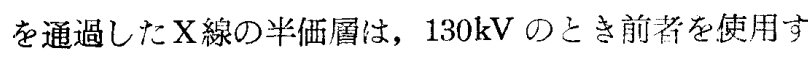
れば $\mathrm{Al} 5.8 \mathrm{~mm}$ であり，後者の場合は $\mathrm{Al} 4.4 \mathrm{~mm}$ であっ た.

$8 \mathrm{~cm}$ パラフインとクロスグリッドを透過するX線量 は. $80 \sim 140 \mathrm{kV}$ の紽网で, $0.05 \mathrm{Cu}+0.1 \mathrm{Al}$ 滤過板の之光 と, $1.18 \mathrm{Al}$ 濾過板のときが同一であった。然しフアン トームの集面に入射するX線量は, $1.18 \mathrm{Al}$ の場合の方 ぶ大であった。即ち銅滤過板の使用に依って，Al 湟渦板

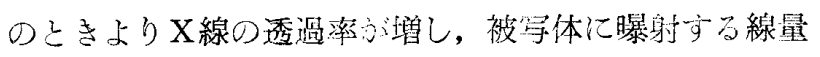
を減少せしめる事が出来号。

$8 \mathrm{~cm}$ パラフインにアルミとアクリライトの段階を取 着汁て， $100 \mathrm{kV}$ 汃ら $150 \mathrm{kV}$ 迄撮影寸る上，1.18 Al滤過 板を使用したるきに粉ぐて， $0.05 \mathrm{Cu}+0.1 \mathrm{Al}$ 濾温板のと きは $\mathrm{Al}$ (盛)とパラフインの間のコントラストの低下が 目立った。然しアクリライト（軟組織）にパラフインの 間のコントラストには㱠ご影響を与えなかった。此の傾 向は特に $140 \mathrm{kV} の と き$ 著明であった。

\section{IV. 結語}

高压撮影用浩過板しして $0.05 \mathrm{Cu}+0.1 \mathrm{Al}$ 使用し， これとアルミ滤遇板この比較実験の結果, 見出したる銅 濾過板の利点在改めて次化列記卞万七。

1. 線質分硬くなる。

2. 被写体の被曝線最方減少する。 
3.アクリライト，パラフイン間（軟組織間）のコン

トラストには始ど影響を与えるこしなく，Al（骨）

の陰影を更に消退せしめる事が出来る。

等である。

波尾切断型コンデンサー式装置は，硬X線の発生能率 が最も良いと云われているが，之に銅濾過板を使用すれ 就更に其の効果を上げ得るものこ信ずる.

（終りにのぞみ終始御指導を賜った，当沂々長立川靖 博士，島津製作所中场孝志博士，並に佐野博也氏，実験 に樍極的なる御協力賜った中唒猛氏に刘し心から感謝の 意を表します。.)
交献

1）吉村，日医放誌，第16巻第 6 号.

2）武田，レントゲン技術.

3) A. Mutscheller, Thichness of Alminium to be used in Addition to Copper Filter, Am. jour, Roent., Vol. 31.

4) M. Grunberg, W. Johner, Über das Alminiumzusatzfittr in der Röntgentherapie Strahlen Therapie, 53, Bd.

5）江藤，人体と放射線.

6）江.䇠，結核研究の進歩，第15号.

7）中垝，日医放誌，第4巻第 1 号.

8）神田，日医放誌，第14巻第10号。

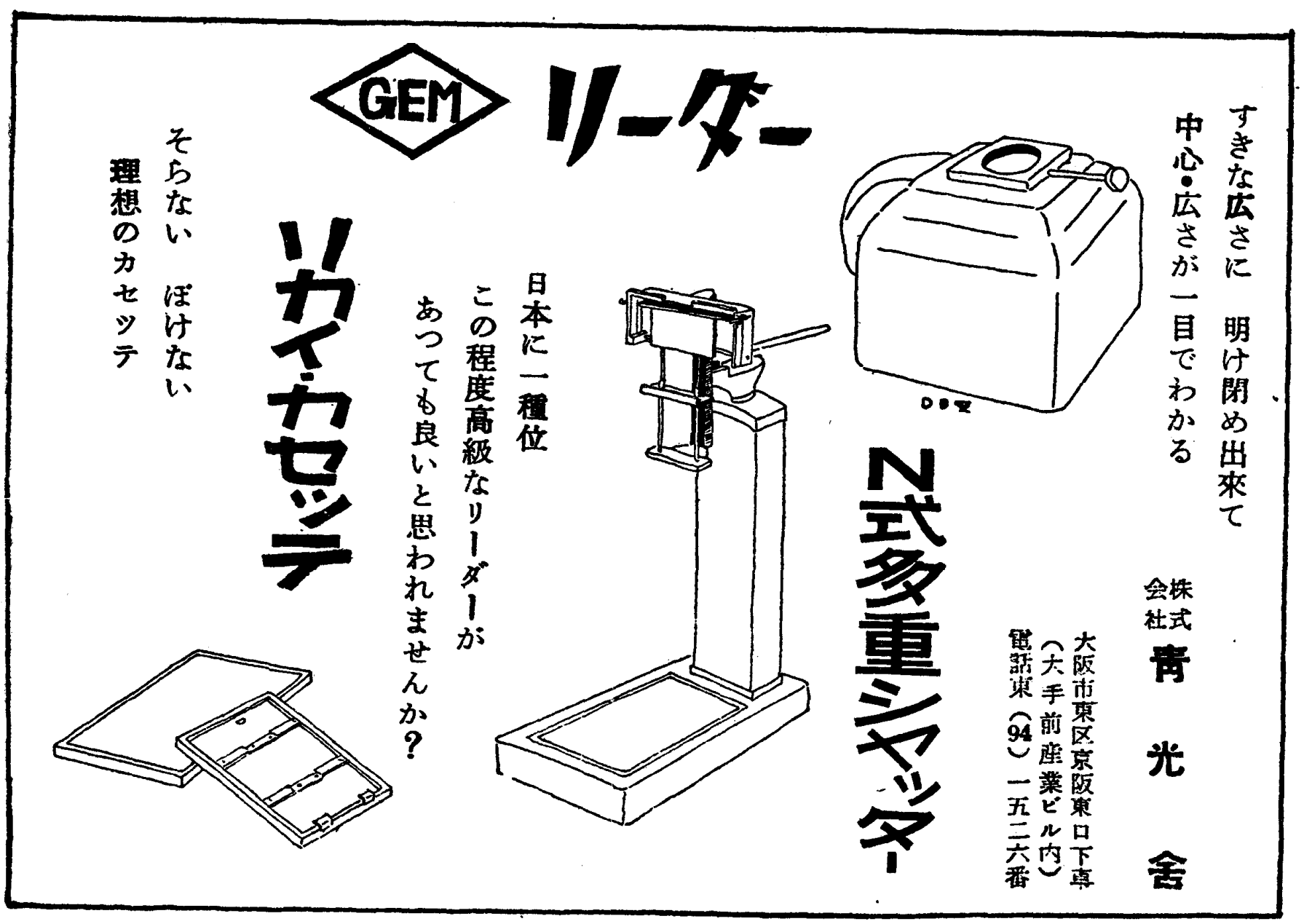

